\title{
Die mens geaffekteer deur kanker: Voorlopige bakens geidentifiseer met die oog op die prediking na aanleiding van Jesus se afskeidsgesprek in die Johannes-evangelie
}

\begin{tabular}{|c|c|}
\hline $\begin{array}{l}\text { Author: } \\
\text { Darius Botha }{ }^{1,}\end{array}$ & \\
\hline $\begin{array}{l}\text { Affiliation: } \\
{ }^{1} \text { Department } \\
\text { Theology, FacL } \\
\text { Theology, Uni } \\
\text { Pretoria, Sout }\end{array}$ & $\begin{array}{l}\text { f Practical } \\
\text { Ity of } \\
\text { ersity of } \\
\text { Africa }\end{array}$ \\
\hline $\begin{array}{l}{ }^{2} \text { Retired pasto } \\
\text { Reformed Chu } \\
\text { Johannesburg }\end{array}$ & $\begin{array}{l}\text { of the Dutch } \\
\text { ch, } \\
\text { South Africa }\end{array}$ \\
\hline $\begin{array}{l}\text { Project Leade } \\
\text { Project Numb }\end{array}$ & $\begin{array}{l}\text { : C.J. Wepener } \\
\text { ar: } 04461012\end{array}$ \\
\hline $\begin{array}{l}\text { Description: } \\
\text { This research } \\
\text { research proje } \\
\text { and Liturgy', d } \\
\text { Dr Cas Wepen } \\
\text { of Practical Th } \\
\text { of Theology, U } \\
\text { Pretoria, Sout }\end{array}$ & $\begin{array}{l}\text { part of the } \\
\text { rect 'Homiletics } \\
\text { rect by Prof. } \\
\text {, Department } \\
\text { hiversity of } \\
\text { Africa. }\end{array}$ \\
\hline $\begin{array}{l}\text { Correspondin } \\
\text { Darius Botha, } \\
\text { botha004@te }\end{array}$ & $\begin{array}{l}\text { author: } \\
\text { komsa.net }\end{array}$ \\
\hline $\begin{array}{l}\text { Dates: } \\
\text { Received: } 26 \\
\text { Accepted: } 25 \\
\text { Published: } 31\end{array}$ & $\begin{array}{l}\text { ct. } 2015 \\
\text { Aay } 2016 \\
\text { Det. } 2016\end{array}$ \\
\hline $\begin{array}{l}\text { How to cite th } \\
\text { Botha, D., } 201 \\
\text { geaffekteer de } \\
\text { Voorlopige ba } \\
\text { geidentifiseer } \\
\text { die prediking } \\
\text { van Jesus se a } \\
\text { in die Johanne } \\
\text { HTS Teologies } \\
\text { Theological St } \\
\text { a3228. http:// } \\
\text { org/10.4102/ }\end{array}$ & $\begin{array}{l}\text { is article: } \\
\text {, 'Die mens } \\
\text { ur kanker: } \\
\text { ens } \\
\text { net die oog op } \\
\text { a aanleiding } \\
\text { skeidsgesprek } \\
\text { s-evangelie', } \\
\text { Studies/ } \\
\text { dies 72(2), } \\
\text { tx.doi. } \\
\text { ts.v72i2.3228 }\end{array}$ \\
\hline Read online & \\
\hline 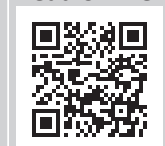 & $\begin{array}{l}\text { Scan this QR } \\
\text { code with your } \\
\text { smart phone or } \\
\text { mobile device } \\
\text { to read online. }\end{array}$ \\
\hline
\end{tabular}

The life of a person affected by cancer becomes a confusion of emotions, experiences and tumultuous events. This takes place with immediate effect and can be summarised in one word 'havoc'. The question that comes to mind in this article is: In which way can preaching guide the person affected by cancer, to equip this person to find both sense and meaning in this life. The farewell speech of Jesus in the Gospel of John will serve as departure for the stipulation of the beacons for the preaching in the guidance of the person affected with cancer. The aim of this article is firstly to show that the person affected by cancer has specific needs concerning preaching, secondly that the farewell speech of Jesus in the Gospel of John assists the preaching with certain beacons and thirdly to motivate that the metaphor of a 'second' is the most suitable for this kind of preaching. The purpose with this article is that the researcher wants to emphasise that the person affected by cancer can still experience sense and meaning in this life.

\section{Inleiding}

Daar is beslis ruimte vir die prediking as dit kom by die mens geaffekteer deur kanker. Die rede vir hierdie opmerking is tweeledig: Eerstens wil dit voorkom asof die getal mense wat geaffekteer word deur kanker aan die toeneem is. Volgens statistiek sal drie uit elke tien mense tydens hulle leeftyd met kanker gekonfronteer word. Tweedens blyk dit dat die prediking oor die potensiaal beskik om die mens geaffekteer deur kanker met sin en betekenis te begelei. Dus die uitdaging wat hierdie artikel ten doel het, is om vanuit die afskeidsgesprek van Jesus in die Johannes-evangelie voorlopige bakens vir die prediking op te rig, waarlangs beweeg kan word in die begeleiding tot sin en betekenis vir die persoon geaffekteer deur kanker hier en nou. Dit is binne hierdie konteks dat die prediking kanker as 'n positiewe gebeure beskou waartydens die mens deur kanker geaffekteer begelei kan word tot nuwe lewensmoontlikhede. Louw (1994:iii) verwoord iets hiervan as hy oor siekte die volgende skryf: 'Illness creates a new understanding of one's calling in life: to represent the loving care of God and become involved in the suffering of others.'

Binne die Suid-Afrikaanse konteks bly dit 'n ope vraag of die mens geaffekteer deur kanker al die volgende kopskuif gemaak het, naamlik: dat die tradisionele siening van ' $n$ kankerdiagnose nie noodwendig die einde beteken nie, maar dat wanneer elke kankerdiagnose op meriete en met omsigtigheid hanteer word, dit duidelik na vore kom dat daar hoop is en dat 'n sinvolle lewe met kanker wel moontlik is (vgl. Brannon \& Feist 2014:loc. 4633). Kanker kan wel 'n lewe tot stiltand bring, maar die lewe stop nie met kanker nie. Die moontlikheid wat in hierdie artikel onderstreep word, is dus dat die mens geaffekteer deur kanker binne die prediking begelei kan word met sin en betekenis.

\section{Navorsingstrategie, doel en metode}

Die betoog van hierdie artikel is dat deur die prediking die chaos wat kanker in die lewe en wêreld van die mens veroorsaak op so 'n wyse aangespreek kan word, dat ten spyte van die chaos wat mag heers, die betrokke mens die lewe met sin en betekenis kan leef. Die rede hiervoor is, dat met die bevestiging van die kankerdiagnose by die betrokke persoon is die veronderstelling dat die mediese uitdaging klaar afgebaken is aan die een kant, maar dat aan die ander kant daar geen

Note: This article represents reworked aspects of the DD dissertation of Dr Darius Botha, titled 'Prediking en die mens geaffekteer met kanker', completed under the supervision of Prof. Dr Cas Wepener and Prof. Dr Cas Vos, Department of Practical Theology, Faculty of Theology at the University of Pretoria, South Africa.

This article is published in the section Practical Theology of the Society for Practical Theology in South Africa.

Copyright: (C 2016. The Authors. Licensee: AOSIS. This work is licensed under the Creative Commons Attribution License. 
duidelikheid oor beskikbare bakens is waarlangs die prediking hierdie persoon tydens hierdie krisistyd kan begelei nie. Hierdie artikel wil juis aan die hand van Osmer (2008) se vier basiese metodologiese vrae binne die praktiese teologie werk op weg na voorlopige bakens vir die prediking in die begeleiding van die mens geaffekteer deur kanker. Volgens Osmer (2008:4) moet die volgende vrae gevra word wanneer daar op soek is na antwoorde vir praktyke wat in die praktiese teologie ontstaan, naamlik, (1) Wat is aan die gebeur? (die deskriptief empiriese taak); (2) Hoe word dié data geïnterpreteer? (die interpretatiewe taak); (3) Wat behoort te gebeur? (die normatiewe taak) en (4) Wat gaan gedoen word om dit te verander? (die strategiese taak).

Dit beteken nie noodwendig dat die voorlopige bakens wat deur hierdie artikel vir die prediking blootgelê word, die enigste bakens vir die prediking verteenwoordig nie. Ander bakens kan ook deur verdere navorsing geïdentifiseer kan word. Dit is binne hierdie basiese prakties teologiese raamwerk dat daar aandag geskenk sal word aan die metafoor van ' $n$ 'second' as wyse van prediking aan die mens geaffekteer deur kanker binne 'n verstelde praktykteorie

\section{Die mens geaffekteer deur kanker (wat is aan die gebeur?) Inleiding}

\section{Omskrywing van siekte in die Bybel}

Siekte ontwrig en skud die lewe van die mens. Volgens Louw en Nida (1988:270-274) word siekte as gevolg van die veelvoudige skakerings daarvan binne die semantiese veld van 'sickness, disease and weakness' hanteer. Dit is belangrik om vir die doel van hierdie artikel tussen 'sickness' en 'illness' te onderskei. Volgens Louw (1994:2) is die onderskeid soos volg, 'sickness implies the state of being and involves a more comprehensive understanding of a person's existential reactions and coping skills according to medical pathology' aan die een kant, terwyl 'illness focuses more on the experiential level of feelings, reactions and emotions connected to a specific disease' aan die ander kant. Die Nuwe Testament onderstreep hierdie veelvoudige skakerings van siekte ('sickness, disease and weakness') met die gebruik van verskillende woorde vir siekte, soos byvoorbeeld:

- Kó $\mu v \omega$ in Jakobus 5:15 met die betekenis van krank

- $\dot{\alpha} \sigma \theta \varepsilon v \varepsilon ́ \omega$ in Lukas 4:40 met die betekenis van kwaal

- $\kappa \kappa \kappa \tilde{c}$ in Matteus 9:12 met die betekenis van ongesteld

- $\lambda \varepsilon ́ \pi \rho \alpha$ in Lukas 5:12 met die betekenis van melaatsheid

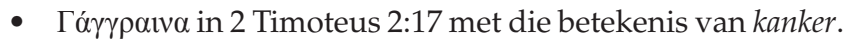

\section{Samevatting}

Die verskillende betekenisse van siekte in die Bybel help om die volgende behoeftes van die mens wat siek is te identifiseer, naamlik: Daar is ' $n$ versteuring in die gesondheid van die mens in die woorde van Overduin (1973:22) 'die oorrompelende vyand'; daar is 'n emosionele versteuring, 'n agteruitgang van die geestelike ingesteldheid, in die woorde van Barth (1951:417) "n teken van chaos'; daar is 'n fisiese versteuring, die liggaam is besig om agteruit te gaan; daar is ' $\mathrm{n}$ vrees vir die ergste, naamlik die dood; daar is onsekerheid in die gemoed van die mens; daar is ' $n$ stigma aan siek wees en siekte is soos ' $n$ onbeheerste mag, dit verwoes 'n mens se lewe.

\section{Die belewing van kanker}

Fred Hutchinson (2016) maak die volgende opmerking wat iets hiervan reflekteer op die webblad van die Cancer Research Center naamlik:

$[L]$ iving with cancer is an experience that can affect every aspect of your life. Not only is your body affected, but also your mind and your spirit. You may experience many emotional reactions to all of these changes.

Lynn Eib (2002) verwoord iets van hierdie ongemaklikheid wanneer sy skryf:

I hate the term cancer victim. It somehow implies cancer is the victor. It wins, we lose. That has not been my experience with cancer patients. While we can do little to choose whether we get cancer, we can do a lot to choose whether we are its victims. I don't just mean whether we live or die. I mean how cancer affects us in the deepest parts of who we are. I believe cancer cannot conquer our spirit unless we choose to become victims. (loc. 69-72)

Volgens Botha (2015:345) wys die empiriese navorsing dat in 'n kankerdiagnose die volgende elemente ter sprake kom, naamlik, (1) die belewenis van die kankerdiagnose; (2) die behandeling na die kankerdiagnose; (3) die ware belewing van die teorie en die praktyk van die kankerbehandeling en (4) die invloed van die kankerdiagnose op verhoudings. Hierdie volg ' $n$ kort bespreking van elke element.

\section{Die belewenis van die kankerdiagnose}

Die belewenis van ' $n$ kankerdiagnose ontlok verskeie reaksies by die mense daarmee gekonfronteer, vir meeste is dit soos 'n indringer, altyd ontydig; ander is weer totaal oorbluf, want dit kan mos nie waar wees nie; dan is daar die mense wat oorweldig word met twyfel en onsekerheid, waarheen nou met die lewe; en laastens is daar diegene wat dit beleef as ' $n$ doodskoot, so uiteindelik het die einde vir my aangebreek.

\section{Die behandeling na die kankerdiagnose}

Die behandeling van kanker is nie so vanselfsprekend as wat dit voorkom nie, want die mens daardeur geaffekteer word, word weer eens met nuwe omstandighede gekonfronteer. Die reaksies kan wissel van die baie positiewe (die hoop en die verwagting) aan die een kant en aan die anderkant die negatiewe (geen waarborge) dat dit uiteindelik goed sal afloop aan die ander kant nie. Daarmee saam loop die druk van familielede, vriende en geesgenote om nie moed op te gee nie.

\section{Die ware belewing van die teorie en praktyk van die kankerbehandeling}

Die mens geaffekteer deur kanker se reis is beslis nie ' $n$ reis van maanskyn en rose nie, omrede die teorie en die praktyk te ver verwyderd is van mekaar. Hierdie ervarings kan ook genoem word die versuservarings, naamlik, (1) die literatuur 
versus die werklike, dit wil sê dit wat die literatuur sê is noodwendig dieselfde as wat in die werklikheid gebeur nie; (2) hoop versus sien, want soms is dit waarvoor (die genesing) gehoop word, nie dit wat werklik gebeur nie, omdat die uiteindelike (die dood) intree; (3) geloof versus ervaar, hier is dit eerder 'n kwessie van 'die gees is gewillig, maar die vlees is swak.' Die mens met kanker word soms gekonfronteer met die feit dat die geloof en dit wat ervaar word nie in balans is nie, dit word geillustreer deur die volgende opmerking, naamlik: 'Ek glo dat my kind gaan gesond word, maar elke keer as ek hom afdroog na hy gebad het sien ek hoe sy liggaam wegkwyn'; (4) behandeling die reg versus die opsie, hier is die kwessie wat ter sprake is bloot 'n uitroep van moenie oor my praat nie, maar praat met my, want dit is tog my kanker wat ter sprake is. Waar dit nie gebeur nie, voel die betrokke persoon uitgesluit en magteloos.

\section{Die invloed van die kankerdiagnose op verhoudings}

'n Kankerdiagnose plaas redelike stres op die verhoudings van die persoon geaffekteer deur kanker, want dit bring ' $n$ stramheid wanneer daar gekommunikeer moet word met die mense betrokke by daardie persoon. Die kuns hier vir die mens geaffekteer deur kanker, is om die verskillende emosies soos skuldgevoelens, bekommernis, vrees, frustrasie en woede so te verwoord dat die onderskeie groepe soos die mediese span, die gesin, die medekankerlyers en die geloofsgemeenskap betrokke nie aanstoot neem nie.

\section{Samevatting}

Die insigte wat hier bekom is sny na twee kante. Eerstens is daar die negatiewe kant van kanker wat deur die prediking verdiskonteer moet word, soos byvoorbeeld die onvoorspelbaarheid van kanker; kanker as die gevreesde vyand; kanker as die bevraagtekening van God se bona fides; kanker as stigma en die meegaande skuldgevoelens. Tweedens is daar die positiewe kant van kanker wat ook in die spel kom as daar nagedink word oor die prediking, soos onder andere die krag van kanker om mense weer saam te bind, die vonk te verskaf wat mense opnuut weer die lewe te laat ontdek en daarmee saam die mens te beweeg om die nou-geleentheid aan te gryp.

\section{Voorlopige bakens uit die afskeidsgesprek van Jesus in die Johannes-evangelie (hoe lyk die data beskikbaar?) \\ Inleiding}

Die hou van afskeidsgesprekke kom 'n redelike lang pad saam met die mens en sy bestaan. Dit het dikwels voorgekom waar die leier of die hoof van 'n spesifieke stam, volk of familie die einde van sy lewe genader het. Hierdie afskeidsgesprek kan vergelyk word met 'n testament.

\section{Afskeidsgesprekke in die Ou Testament}

Die meeste literatuur wys ook daarop dat afskeidsgesprekke deel was van die menslike bestaan en dat dit in die Bybelse- sowel as buite-Bybelse literatuur voorgekom het. Voorbeelde van afskeidsgesprekke in die Bybel is die van Isak (Gen 27), Jakob (Gen 47:29-49:33), Moses (Deut 31-33), Joshua (Jos 23-24), Samuel (1 Sam 12) en David (1 Kron 28-29). Die voorlopige bakens met die oog op die prediking vanuit die Bybelse voorbeelde van afskeidsgesprekke lyk soos volg, naamlik:

- Samekoms vind plaas

Daar word ' $n$ geleentheid geskep waartydens die geaffekteerde persoon met die naasbestaandes die gebeure wat op hande is, kan bespreek.

- Intieme gesprek

Tydens hierdie geleentheid word die herinneringsvermoë van die geaffekteerde persoon gebruik om die naasbestaandes se gedagtes lewend te hou vir die pad wat voorlê. Die gesprek is ernstig en intiem, want die naasbestaandes moet besef dat moeilike tye hulle voorland is.

- Wegstuur met troos

Die oogmerk van hierdie geleentheid is nie net die oordrag van funksies en pligte aan die belanghebbendes nie, maar ook om hulle te begelei vir dit wat voorlê. Die doel van die afskeidsgesprek is tweeledig: Aan die een kant is dit dat die $\approx$ geaffekteerde persoon tevredenheid kan ervaar en aan die ander kant dat die naasbestaandes met rustigheid en hoop kan vorentoe kyk.

\section{Die afskeidsgesprek van Jesus in die Johannes- evangelie}

Die afskeidsgesprekke van Jesus in Johannes 13:1-17:26 impliseer 'n soortgelyke struktuur as die van die afskeidsgesprekke wat in die Bybel voorkom, die volgende kommentare $^{1}$ kan in die verband met vrug geraadpleeg word. Die struktuur lyk soos volg, naamlik:

- 'n Samekoms vind plaas

Die tyd het vir Jesus aangebreek om die dinge vir sy dissipels in perspektief te plaas. Hy moes die dissipels inlig dat die goeie wat die Vader in hom begin het, voortgesit moet word totdat Hy (Jesus) weer terugkeer om finaal oor alles en almal te triomfeer. Jesus moet sy dissipels so begelei dat hulle wat agterbly, wel bereid sal wees om met die werk wat God in Jesus gedoen het voort te gaan.

- Daar is ' $n$ intieme gesprek

Die intieme gesprek van Jesus met die dissipels is daarop gerig om eerstens duidelik te maak dat $\mathrm{Hy}$, die Christus is, die Seun van God, en tweedens dat as gevolg daarvan hulle dissipelskap ' $n$ integrale deel hiervan vorm. Du Rand (1979:17) bevestig bogenoemde met sy opmerking dat, 'dit is belangrik om daarop te let dat die groot gedagtes van hoofstuk 13 afspeel teen die agtergrond van die betekenis van dissipelskap.' Die dissipels se sinvolle agterbly nadat Jesus vertrek het, hang ten nouste saam 1.Stevic (2011); Culpepper (1983); Ridderbos (1997); Schnackenburg (1977); Tolmie (1995); Waetjen (2005) and Van der Watt (2000). 
met die inhoud van hulle dissipelskap en die konkretisering daarvan in hulle optrede.

- Dan die wegstuur met troos

Volgens Louw en Nida (1988:142) word die begrip

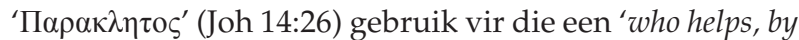
consoling [troos], encouraging [bemoedig], or mediating on behalf of' [tussenbei(de) kom]. Die afleiding word gemaak

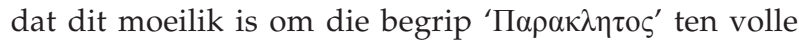
bevatlik te maak, as gevolg van die wye betekenis wat daaraan geheg word. Die tradisionele term van 'comforter' is beperkend, omdat dit misleidend is, want dit fokus slegs op 'n enkele aspek van wat die Heilige Gees doen. Waar 'n term soos 'Helper' meer generies, maar ook meer veelsydig in ander tale is. Die Heilige Gees vergestalt iets van ' $\mathrm{n}$ 'Helper', in die woorde van Louw en Nida (1988):

$[T]$ he one who mothers $[\ldots]$, the one who falls down besides [...], that is to say, a [Helper] [is] an individual who upon finding a person collapsed along the road, kneels down beside the victim, cares for his/her needs, and carries him/her to safety. (bl. 142)

Die Parakleet se koms in die plek van Jesus is die bonus op die dissipelskap. Die Parakleet ${ }^{2}$ as 'Helper' hou die volgende voordele in vir die dissipels, naamlik, (1) dat Jesus in en vir altyd deur die Heilige Gees by hulle teenwoordig sal wees (troos); (2) dat hierdie teenwoordigheid van Jesus in die 'Helper' verseker dat die dissipels se geloof gestu en versterk (bemoedig) word en (3) dat dit belangrik is om te sien dat die dissipels nie uit die wêreld weggeneem sal word nie, maar hier in die wêreld deur die 'Helper' begelei sal word.

\section{Samevatting}

Dus vanuit die afskeidsgesprekke van Jesus kan die volgende funksies van die 'Helper' onderskei word, naamlik, (1) Troos: Die 'Helper' onderstreep die ideologiese perspektief dat om volgeling van Jesus te wees, nie ' $n$ maklike weg is nie. Die feit dat ' $n$ volgeling iemand is wat in Jesus is en bly, is geen vrywaring teen ellendes en krisisse nie. Die 'Helper' se teenwoordigheid is die versekering dat hulle wel die mas sal kan opkom deur te vra wat nodig is. Die 'Helper' se begeleiding en versorging dra daartoe by dat die volgeling die Vader en Jesus se teenwoordigheid beleef wat uitloop op vreugde (vgl. Tolmie 1995:211). (2) Bemoediging: Die wêreld haat die dissipels omdat hulle Jesus haat. In hierdie proses is die rol van die 'Helper' belangrik, want Jesus het juis die 'Helper' gestuur as die 'Gees van waarheid' en hierin is dit van belang dat die volgeling moet besef dat die wêreld se verwerping van Jesus ook na die volgeling kan oorspoel. Die feit bly egter staan dat die volgeling van Jesus nooit alleen gelaat sal word in hierdie wêreld nie. Die volgeling van Jesus moet egter voortdurend bewus wees dat die geloof in hierdie lewe altyd onder druk sal wees, as gevolg van die bedreigings van die lewe (vgl. Tolmie 1995:213-216). (3) Tussenbei(de) tree: Die vertrek van Jesus uit hierdie wêreld terug na die Vader, bring die 'Helper' (Parakleet) se koms en funksie na vore. Die 'Helper' se taakbeskrywing het betrekking op die wêreld, asook op Jesus se volgelinge. Die dissipels se verbouereerdheid is 'n uitvloeisel van Jesus se weggaan na die Vader en daarom moet hulle daarop bedag wees dat hulle baie sal moet verduur vir hulle dissipelskap. Dit gaan egter verby en vreugde wag op hulle, want Jesus is direk met hulle in kontak deur die 'Helper' (vgl. Tolmie 1995:216-221).

\section{Die metafoor 'second' (Helper) as preekstyl in die begeleiding van die mens geaffekteer deur kanker (wat behoort te gebeur?) Die ryke betekenis van metafore}

Die ryke betekenis van die metafoor lê daarin dat dit die mens se verbeelding vrye teuels gee. Volgens Vos, Hogan en Cilliers (2007) is:

Metaphors are explosive and their force hurls people towards new insights and blasts open new worlds. Metaphors that enlighten the faithful, also enable them to experience surprises and moments of awe in their everyday life. (p. 22; vgl. ook Van Huyssteen 1987:159; 1997:188; Fourie 2010:11)

Vos (2002:160-162) wys ook daarop dat 'die trefkrag, die nuutheid en die varsheid' van metafore lê in funksies soos, (1) dit help om die onbekende in terme van die bekende te verstaan; (2) dit verbind verbandhoudende werklikhede, wat beteken dat dit die aandag vestig op twee realiteite wat op een of ander manier met mekaar verband hou; (3) dit moet alledaags wees, dit wil sê gegrond wees in die alledaagse ervaringe van hoe mense dink en met die wêreld kommunikeer om nuwe moontlikhede en uitsigte te skep en (4) dit moet konteksgebonde wees wat beteken dat die 'die primêre eenheid van betekenis lê in die sin en nie in die woord nie' (vgl. Ricoeur 1977:44). Dus as daar na metaforiese taal verwys word, gaan dit nie slegs om 'n funksie van woorde nie, maar ook om die totale ko(n)teks waarbinne woorde (frases) gebruik word en (5) dit beskik oor towerkrag, want dit kan aan 'n nuwe werklikheid vorm gee en dit kan die liturg help om as towenaar binne die erediens God se nuwe wêreld te ontsluit. (vgl. Morgenthaler 2002:130).

\section{Bestaande metafore binne die prediking}

\section{Inleiding}

In hierdie verband is dit dus noodsaaklik om voortdurend na nuwe metafore te soek om die homiletiese verbeelding te bly stimuleer. Metafore, as woorde wat binne 'n ongewone konteks gebruik word, help ons juis om nuwe insigte te gee (Nell 2009:819). Dit is redelik bekend dat metafore 'n belangrike hulpmiddel is om ons verbeelding te stimuleer en ons nuwe moontlikhede te laat antisipeer. Daarom is dit interessant om op te let hoe nuwe metafore in homiletiese navorsing die verbeelding stimuleer (vgl. bv. Lowry 1997; Engemann 2001; Hilkert 1997; Childers 1998; Cilliers 2002). 


\section{Metafore wat tans binne die prediking voorkom}

Long (2005) en De Vries (2010) onderskei die volgende metafore (beelde) binne die prediking, naamlik, (1) Die leraar as beeld van die 'onderwijzende model', waar die doel van die preek is om die hoorder te leer oor die waarheid van die Bybel of oor ware geloof. Die konteks van die teks geniet voorrang bo die konteks van die hoorder. (2) Die boodskapper as beeld van die 'kerugmatiese model', waar die prediking die verkondiging is van God se heil, wat volgens Long (2005:19) so verwoord kan word dat 'the preacher is the one who speaks the words of the sermon, but God actually does the proclaiming.' (3) Die pastor en herder as beelde van die 'gespreksmodel', waar die prediking die hoorders help met hulle vrae. Randall Nichols (1987:16) stel dit duidelik dat die prediking 'deliberately sets out to touch and to involve people's personal concerns.' Die pastor beskou die prediking 'as healing words addressed to concrete situations of human need' (Long 2005:31). (4) Die storieverteller as beeld van die 'narratiewe model', waar die preek die hoorder met sy lewensverhaal betrek by die verhaal van die Bybel. Jana Childers (1998) praat daarvan:

$[P]$ reaching had been going through its own changes. The kerygmatic preaching of the sixties gave way in the seventies to an interest in inductive preaching. The eighties brought an emphasis on narrative and imagination. By the nineties few people were shocked when preaching was referred to as an art. (bl. 11)

Hoorders wil met hulle stories inhaak by die storie van God om so tot ' $n$ nuwe verstaan te kom oor God se betrokkenheid by hulle lewe. (5) Die getuie as beeld is eie aan die Bybel, sien Handelinge 1:8: 'maar julle sal krag ontvang wanneer die Heilige Gees oor julle kom en julle sal my getuies wees.' Hierdie 'belydende model' dui daarop dat die pastor eksistensieel betrokke is by sy hoorders (Long 2005:45-51). ${ }^{3}$ Die preek is 'n getuienis, wat beteken dat die prediker ' $\mathrm{n}$ belydende posisie inneem om van eie ervarings en belewenisse met die hoorders te deel in die omgaan met die Woord. Die funksie van die preek is die vorming van geloof.

\section{Bestaande modelle in die hantering van mense geaffekteer deur kanker}

\section{Inleiding}

Die reis deur die verskillende benaderings in die begeleiding van mense geaffekteer deur kanker het gelei tot die gevolgtrekking dat elke model op 'n eie unieke manier daartoe bydra dat die betrokke persoon met kanker in totaliteit hanteer word.

\section{Bestaande modelle wat tans gebruik word \\ Fasemodel (Fawzy \& Fawzy 1982)}

Fawzy en Fawzy onderskei die volgende fases tydens die reis met kanker, naamlik, (1) die diagnose, dit wil, sê die bepaling van die soort-, die aard- en die moontlike vooruitsigte ten opsigte van die bepaalde kanker; (2) die behandeling, dit wil sê,watteropsiesisbeskikbaaruitdiebehandelingsmoontlikhede van chemoterapie, radiobestraling, chirurgie en alternatiewe metodes soos byvoorbeeld stamseloorplanting; (3) die opvolg, dit wil sê, die monitering van die vordering van die pasiënt tydens die behandelingsfase; (4) die terugval, dit wil sê, die bewus wees van die moontlikheid dat die kanker terug kan kom; (5) die terminale fase waartydens die pasiënt begelei en ondersteun word op die moontlikheid van dood. Hierdie benadering lei daartoe dat die mens met kanker nie bloot as 'n objek beskou kan word nie, en steeds met liefde en respek hanteer behoort te word.

\section{Fasemodel (Kübler-Ross 1969)}

Kübler-Ross se benadering is geskoei op die emosies wat na vore gekom het uit haar gesprekke met haar pasiënte wat op sterwe gelê het. Sy het hierdie emosies gegroepeer en het daaruit die volgende emosies geïdentifiseer, naamlik, (1) ontkenning, (2) woede, (3) onderhandeling, (4) depressie en (5) aanvaarding. Die krisis met die fasebenadering van KüblerRoss is dat die mens geaffekteer deur kanker nie noodwendig aan sterwe is nie. Hierdie benadering onderstreep ' $n$ belangrike faset in die begeleidingsproses, en dit is om te luister na die behoeftes van die mens geaffekteer deur kanker.

\section{Berustingsmodel (Hechter, Poggenpoel \& Myburgh 2001)}

Hechter, Poggenpoel en Myburgh het met hulle berustingsmodel tot die gevolgtrekking gekom dat die gesin met ' $n$ terminale kankerkind se leefwêreld die volgende veranderings ondergaan, naamlik, (1) die reaksie op kanker is ' $n$ keuse, (2) die familiewaardes verander radikaal, (3) aanvaarding bring berusting, (4) die hier-en-nou raak geweldig belangrik en (5) die makliker aanvaarding van hulp van buite die gesin. Hierdie benadering weerspieël iets van die afskeidsgesprek van Jesus met sy dissipels, want daar vind 'n verdieping plaas ten opsigte van die mense betrokke hierby en ten opsigte van die viervoudige verhouding van die mens tot God, tot hom- of haarself, tot die medemens en tot die omstandighede hier en nou.

\section{Taakgebaseerdemodel (Corr 1991-1992)}

Corr se taakgebaseerde benadering is daarop gerig dat die mense met kanker nie net op die negatiewe kant, byvoorbeeld die lyding, moet fokus niemaar ook verder moet kyk as die lyding, sodat dit wel met hoop en verwagting beheer kan word. Hier word gefokus op die vlakke van die fisiese, die sielkundige, die sosiale en die geestelike met die oog op bemagtiging, sodat die mens geaffekteer deur kanker in staat is om daarmee saam te kan leef. Die uitgangspunt hier is om die mens met kanker te help om die regte keuses te maak, sodat die lewe hier en nou sin en betekenis kan hê.

\section{Versigtigheidsmodel (Zurheide 1997)}

Zurheide se versigtigheidsbenadering beklemtoon dat die helper nie net die mens geaffekteer deur kanker se omstandighede kan binne storm nie, maar dit eerder met versigtigheid moet benader met die oog daarop om verligting te bring. Die mens wat met kanker leef, is nie net ' $\mathrm{n}$ voorwerp 
wat heen en weer geskuif en vervoer kan word na gelang van omstandighede nie. Die versigtigheidsbenadering poog nie om die reis met kanker te romantiseer nie. Die mens geaffekteer deur kanker is soms net opsoek na 'n bietjie stilte, begrip en 'n glimlag. Die versigtigheidsmodel beklemtoon dat die naderkom met begrip en verstaan verwelkom word.

\section{Presentiemodel (Baart 2011)}

Die 'Presentie'-benadering berus op die blootstelling van die mense (met kanker) in nood aan die helpers. Hierdie blootstelling vereis die volgende aksies, naamlik, (1) 'n toe mond, (2) die raaksien van die ander, (3) en die beskikbaarheid om iets vir die ander te kan doen. Die sukses van die 'presentie' model lê in die bewusmaking vir die ander persoon (met kanker) in nood.

\section{Samevatting}

Kanker is onvoorspelbaar en kan soos 'n ongenooide gas enige tyd van die dag of die nag aan die deur van die mens se lewe klop. Die woord 'kanker' bly nog steeds die mees pynlike woord in die woordeskat van menswees. Kanker ontstig mense se verhoudings, denke, fisiese, geestelike en eksistensiële wêrelde. Tog is daar lig aan die einde van die tonnel, want aan hoop en durf ontbreek dit nie by die mens wat' $n$ pad met kanker stap nie.

\section{Die metafoor van die 'second' as die voorlopige vorm vir die prediking by die mens geaffekteer deur kanker (wat moet gebeur en hoe gaan dit gebeur?) \\ Inleiding}

Die gevolgtrekking uit die bondige bespreking van bogenoemde metafore en modelle met die oog op die daarstelling van ' $n$ vorm van prediking wat as gepas beskou kan word vir die mens geaffekteer deur kanker, is kompleks. Corr (1991-1992) wys daarop dat so 'n vorm (model) vier funksies moet verrig, naamlik:

(1) Provide a basis for understanding all of the dimensions and all of the individuals that are involved in coping with dying [cancer]; (2) Foster empowerment for those who are coping with dying [cancer] by emphasising the options available to them as they live out what is often a difficult time in life; (3) Emphasising participation or the shared aspects of coping with dying [cancer] - those aspects whereby people draw together in small communities and assist each other in interpersonal networks; (4) Provide guidance for care providers and helpers, whether they are professionals, volunteers or family members. (bl. 82)

Die outeur is oortuig dat die afskeidsgesprek van Jesus met sy dissipels in die Johannes-evangelie beslis raakpunte het met die funksies van 'n model (vorm) volgens Corr. Nadat die metafoor van die 'second' ('n Helper) met my verbeelding op loop gesit het, was dit interessant om te sien hoeveel navorsing reeds in hierdie verband gedoen is (vgl. Botha 2011; Venter 1991).

\section{Voorlopige bakens vir die prediking binne die afskeidsgesprek van Jesus}

Die afskeidsgesprek van Jesus sluit nou aan by die funksies van die model (vorm) soos uiteengesit deur Corr (1991-1992:82). Die funksies is voorlopers vir die voorlopige bakens gerig op die vormgewing van die prediking aan die mens geaffekteer deur kanker. Hierdie voorlopige bakens word soos volg onderskei, naamlik, (1) begrip vir die omstandighede wat beteken dat Jesus weet die einde van sy aardse reis is op hande en hieroor moet hy die mense (sy dissipels) wat naby Hom leef inlig; (2) bemagtiging in moeilike tye wat meebring dat die afskeidsgesprek 'n spanningsvolle oomblik is, want die een wat voorgaan (Jesus), is die een wat homself stroop oor die kortstondigheid van die menslike lewe, die einde het aangebreek en hieraan kan niemand verander nie; (3) bevestiging van die deelname aan die plan van God en dit is hier waar die narratiewe ' $n$ belangrike rol speel, want in die storie wat gedeel word moet die wat agterbly, gelei word om sin te maak uit dit wat aan die gebeur is. Johannes wil deur die afskeidsgesprekke van Jesus beklemtoon dat Jesus se koms na hierdie wêreld deur God bestem is; (4) begeleiding van die wat betrokke is by die plan van God, want die afskeidsgesprek van Jesus is ook ' $n$ stukkie 'heilige grond', wat beteken dat dit ' $n$ baie intieme geleentheid is, dit is 'n geleentheid wat weg van die publieke oog gebeur. Die afskeidsgesprek is ook 'n oorgangsfase, waar die een wat voorgaan die onrustigheid wat deur sy weggaan veroorsaak is wil bestuur, sodat hulle wat agterbly met moed en vreugde dit wat voorlê aanpak.

\section{Die beeld van die 'second' ('n Helper)}

\section{Inleiding}

Teen die agtergrond van bovermelde modelle, tesame met perspektiewe vanuit die navorser se eie ervaring oor jare heen in hierdie veld, word daar vervolgens oorgegaan tot die formulering van die 'second' (Helper) model vir die prediking in die begeleiding van die mens geaffekteer deur kanker tot lewensin en lewensvreugde. In hierdie opsig word daar gebruik gemaak van Long (2005:136-141) se werkswyse, waarin hy drie stappe volg: (1) begin by die fokus en die funksie van die preek; (2) verdeel die fokus en die funksie van die preek in kleiner gedeeltes; en (3) bepaal die volgorde van die gebeurtenisse binne die preek.

\section{Die 'second' (Helper) as voorlopige vorm vir die prediking}

Daar word in besonder gefokus op die boodskap van die afskeidsgesprek van Jesus met sy dissipels vir die daarstelling van 'n voorlopige vorm vir die prediking met die oog op die begeleiding van die mens geaffekteer deur kanker. Die prediker as getuie staan tussen die getuienis wat oorgedra gaan word en die mense wat die getuienis gaan hoor, elkeen met sy eie aandeel in die vorm van die preek (Long 2005:136). Die analoog hiervan in die afskeidsgesprek van Jesus met sy dissipels is die volgende, naamlik: (1) Jesus, die Seun van God word gestuur om die Vader se plan tot uitvoer te bring; (2) dat daar ' $n$ radikale verskil is tussen ' $n$ dissipel van Jesus wees of 'n volgeling van die wêreld; (3) die verhouding 
tussen Jesus en sy dissipels is bepalend vir hulle op weg in hierdie wêreld; (4) dissipelskap het beslis implikasies vir die lewe van 'n dissipel; (5) realistiese dissipelskap sluit ook moeilike tye in; (6) die seëninge van dissipelskap loop uit op die moed, die hoop en die durf wat nodig is vir dit wat voorlê.

Tom Watson, die Ryder Cup-kaptein van die Amerikaanse span het tydens die trofeeseremonie, die volgende woorde van die Amerikaanse President Roosevelt voorgelees:

It is not the critic who counts, not the one who points out how the strong man stumbled or how the doer of deeds might have done them better. The credit belongs to the man who is actually in the arena; whose face is marred with sweat and dust and blood; who strives valiantly; who errs and comes short again and again; who knows the great enthusiasms, the great devotions and spends himself in a worthy cause and who, if he fails, at least fails while bearing greatly so that his place shall never be with those cold and timid souls who know neither victory nor defeat (Feinstein 1995:52).

Hierdie woorde bevat iets van die mens wat met kanker saamleef en juis daarom wil die geloofsgemeenskap betrokke wees by die mens geaffekteer deur kanker. Hierdie betrokkenheid moet volhoubaar en ondersteunend wees vir elkeen wat stry teen die groot ' $K$ '. Die gekombineerde beeld van die prediker in die kop van die navorser is die van 'n 'Helper' (a second). Die betekenis hiervan word in die Word Power Dictionary soos volg beskryf: 'as a person who assists a competitor in a sport' (Readers Digest 1996:992). Die fokus van die 'Helper' ('a second') is op die ondersteuning van die een wat in die stryd betrokke is. Dit is die gedagte wat by die afskeidsgesprek van Jesus ook na navore kom. Die 'Helper' wat van die Vader en Jesus uitgaan is daar ter ondersteuning van die dissipels, om hulle te 'help' met hulle dissipelskap (vgl. Tolmie 1995:228-229). Die rol van die 'Helper' ('a second') word effektief geilllustreer in die volgende aksies:

- Reik die hand: By die afskeidsgesprekke neem die verhaal van Jesus 'n duidelike wending; Jesus se fokus is nou op die binnekring van sy eie volgelinge en daarop volg die gevangeneming, verhoor, kruisiging en opstanding. Jesus wil deur hierdie gebaar sy dissipels gerus stel. Hy wil onderstreep dat sy sending na hierdie wêreld nie tevergeefs was nie en dat, al voel hulle onseker, hoef hulle nie so te voel nie, want $\mathrm{Hy}$ is ten volle in beheer en die 'Helper' (die Parakletos) sal hulle hierin begelei en versorg.

- Vat die hand: Met die bekendmaking van Jesus se teruggaan na die Vader en die openbaarmaking van die verraaier, was daar onsekerheid en vrae in die gemoed van die dissipels. Tydens hierdie innerlike worsteling in die gemoed van die dissipels, kom Jesus toe en deur woorde en dade van die 'Helper', skep hy weer rustigheid in die gemoed van die dissipels.

- Lei die hand: Jesus neem die dissipels nie net by die hand nie, hy lei hulle ook sodat hulle kan besef dat hulle verhouding met Jesus nie te versmaai is nie, maar werklik sin en betekenis het. Hy vertel hulle wat aan die gebeur is en wat nog gaan gebeur, sodat wanneer dit gebeur hulle nie oningelig sal wees nie. Hy verseker hulle ook van die 'Helper' wat sal kom na Sy weggaan om hulle in die volle waarheid te kom lei.

- Los die hand: Jesus beklemtoon dat sy weggaan tydelik is, maar dat dit ' $n$ noodsaaklikheid is, omrede dit 'n aantal gebeurtenisse aan die gang sit wat tot hulle voordeel sal wees. Jesus se weggaan beteken ook dat die dissipels vir die eerste keer verantwoordelikheid moet neem, sodat wat Jesus kom vestig het, volhoubaar kan wees.

\section{Samevattend}

Die mens geaffekteer deur kanker, is terdeë bewus van die uitdagings en die eise wat gestel word tydens die reis met kanker. Dit laat opnuut die besef dat niemand namens die mens geaffekteer deur kanker hierdie reis kan voortsit en voltooi nie. Dit laat die behoefte by die mens geaffekteer deur kanker hunker na iemand soos 'n 'Helper': iemand wat nie wil oorvat nie, maar wil help tydens hierdie reis met kanker. Die kankerreis as sodanig is reeds ' $n$ Mount Everest ekspidisie, wat daarop kan dui dat die mens geaffekteer deur kanker nie behoorlik daarvoor toegerus is nie. Die behoefte is dan aan iemand wat daar is, iemand wat in plek is, iemand op wie gesteun kan word en iemand wat ruimte skep vir die mens geaffekteer deur kanker. Die beeld wat onmiddellik in die gedagte na vore tree, is die van 'n 'Helper' (a second) wat beteken: om die hand te reik; om die hand te vat; om die hand te lei en ook op ' $n$ stadium die hand te los, sodat die mens geaffekteer deur kanker die reis sinvol en vreugdevol kan voltooi.

\section{Erkenning Mededingende belange}

Die outeur verklaar dat hy geen finansiële of persoonlike verbintenis met enige party het wat hom nadelig of voordelig kon beïnvloed het in die skryf van hierdie artikel nie.

\section{Literatuurverwysings}

Baart, A., 2011, Een theorie van de presentie, Boom uitgevers, Den Haag. Barth, K., 1951, Kirchliche Dogmatik III/4, Evangelischer, Zollikon-Zürich.

Botha, D.S., 2015, 'Prediking en die mens geaffekteer deur kanker', Proefskrif, Departement van Praktiese Teologie, Universiteit van Pretoria.

Botha, J.S., 2011, 'Kreatiewe prediking: kreatiwiteit in diens van die Heilige Gees in die ingewing van die preek', Proefskrif, Departement van Praktiese Teologie, Universiteit van Pretoria.

Brannon, L. \& Feist, J., 2014, Health psychology: An introduction to behaviour and health, 6th edition, Kindle edn., Cram Publishing, n.p.

Childers, J. 1998, Performing the Word, Abingdon, Nashville.

Cilliers, J.H., 2002, 'Die geheim van die prediking: in stemming met die gemeente', Hervormde Teologiese Studies, 58(1), 143-156.

Corr, C., 1991-1992, 'A task-based approach to coping with dying', Omega 24(2), 81-94.

Corr, C.A., 1993, 'Coping with dying: Lessons that we should and should not learn from the work of Elisabeth Kubler-Ross', Death Studies 17(1), 69-83.

Culpepper, R.A., 1987, Anatomy of the Fourth Gospel: A study in literary design, Kindle edn., Fortress Press, Philadelphia.

De Vries, R., 2010, 'De opbouw van de preek', in H. van der Meulen (red.), Als een leerling leren preken, pp. 100-110, Uitgeverij Boekencentrum, Zoetemeer.

Du Rand, J.A., 1979, Johannes 13 by die maaltyd, Academia, Pretoria. 
Eib, L., 2002. When god and cancer meet. True stories of hope and healing, Kindle edn., Tyndale House Publishers, Inc., Carol Stream.

Engemann, W., 2001, 'On man's re-entry into his future: the sermon as creative act', lesing aangebied tydens die Internasionale Homiletiese Werkgemeenskap deur die Societas Homiletica 5th International Conference Utrecht, The Netherlands 2001.

Fawzy, F.I. \& Fawzy, N.W, 1982, 'Psychosocial aspects of cancer', in D.W. Nixon Diagnosis and management of cancer, pp. 111-123, Addison-Wesley, London.

Feinstein, J., 1995, A good walk spoiled, Warner Books, London.

Fourie, M.C., 2010, 'Middelloopbaan-ontwikkeling deur spirituele lewenstylafrigting', proefskrif, Departement van Praktiese Teologie, Universiteit van die Vrystaat.

Hechter, S., Poggenpoel, M. \& Myburgh, C., 2001, Life stories of families with a terminally ill child, Curationis 24(2), 54-61.

Hilkert, M.C., 1997, Naming grace: preaching and the sacramental imagination, Continuum, New York.

Hutchinson, F., 2016, Cancer Research Center, viewed 24 August 2016, from http:// www.fhcrc.org/

Kübler-Ross, E., 1969, On death and dying, Scribner, New York.

Long, T.G., 2005, The witness of preaching, 2nd edn., Westminster John Knox Press, Louisville.

Louw, D.J., 1994, Illness as crisis and challenge, Orion Publishers, Halfway House.

Louw, J.P. \& Nida, E.A., 1988, Greek-English Lexicon of the New Testament based on semantic domains, vol. I \& II, United Bible Societies, New York.

Lowry, E.L., 1997, The sermon: dancing the edge of mystery, Abingdon, Nashville.

Morgenthaler, C., 2002, Systematische Seelsorge, 3. Aufl., Kohlhammer, Stuttgart.

Nell, I.A., 2009, 'In die gastehuis van die prediking: Preekvernuwing vanuit Bybelse en gereformeerde wortels', In die Skriflig 43(4), 817-840.

Nichols, J.R., 1987, The restoring Word: Preaching as pastoral communication, Harpe \& Row, San Francisco.
Osmer, R., 2008, Practical theology: An introduction, Eerdmans, Grand Rapids.

Overduin, J., 1973, Die kunst van het ziek zijn, Kok, Kampen.

Reader's Digest, 1996, sv. 'second', Southern African word power dictionary: Improve your English as you build your vocabulary, Reader's Digest Association South Africa, Cape Town.

Ricoeur, P., 1977, The rule of metaphor. Multi-disciplinary studies of the creation of meaning in language, Routledge and Kegan Paul, London.

Ridderbos, H.N., 1997, The Gospel of John: A theological commentary, Kindle edn. William B.B. Eerdmans Publishing Company, Grand Rapids.

Schnackenburg, R., 1977, Das Johannesevangelium, III. Teil, zu Kap. 13-2, Herder, Freiburg.

Stevick, D.B., 2011, Jesus and his Own, Kindle edn., Wim B. Eerdmans, Michigan.

Tolmie, D.F., 1995, Jesus' farewell to the disciples: John 13:1-17:26 in narratological perspective, E.J. Brill, Leiden.

Van den Berg, J.H., 1952, Psychologie van het ziekbed, Callenbach, Nijkerk.

Van der Watt, J.G., 2000, Family of the King, Koninklijke Brill NV, Leiden.

Van Huysteen, W., 1987, Teologie as kritiese geloofsverantwoording, Raad vir Geesteswetenskaplike Navorsing, Pretoria.

Van Huyssteen, W., 1997, Essays in postfoundationalist theology, Eerdmans, Grand Rapids, MI.

Venter, C.J.H., 1991, “Jou enigste troos”: Pastorale perspektiewe en motiewe uit die Heidelbergse Kategismus', In die Skriflig 25(1), 47-69.

Vos, C.J.A., 2002, 'Beeldende taal: Bybel en poësie', Hervormde Teologiese Studies 58(1), 157-171.

Vos, C.J.A., Hogan, L.L. \&Cilliers, J.H., 2007, Preaching as a language of hope, Pretoria Book House, Pretoria. (Studia Homiletica, 6).

Waetjen, H.C., 2005, The Gospel of the beloved disciple, T \& T Clark International, New York.

Zurheide, J.R., 1997, When faith is tested, Kindle edn., Fortress, Minneapolis. 